\title{
The Evolution of the Virtuality Phenomenon in Organisations: A Critical Literature Review
}

\author{
Mehmet A. Orhan
}

\begin{abstract}
A B S T R A C T
Objective: The purpose of this study is to present a review of the scholarly literature development on virtual teams and to redefine the key characteristics and features of 'team virtuality' and 'virtual teams'. Even though previous literature reviews enhanced the understanding of the implications brought about by virtual teams, this study differs from earlier studies in a number of ways.

Research Design \& Methods: A literature review through content and citation analyses was conducted using the Web of Science, ABI/Inform and EBSCO databases in order to comprehensively explore all definitions and characteristics of the concepts of 'virtual team' and 'team virtuality'. A total of 265 articles published between 2006 and 2014 were analysed, and the details of the analyses are herein presented.
\end{abstract}

Findings: The analyses reveal that the characteristics and definitions are often contradictory and rarely correspond, thereby attesting to the lack of consensus in the literature. I present a portrait that tackles the literature's focus on virtual team's geographic dispersion and its dependency on electronic communication as the core sources of virtuality, as a defining characteristic of virtuality remain to be the lack of face-to-face contact.

Implications \& Recommendations: The major implication is that a unified definition is proposed in order to measure virtuality more comprehensively by addressing the gap observed in past research.

Contribution \& Value Added: This article contributes to the literature incorporating the studies from the most extensive fields of research. After considering different approaches and dimensional constructs, it has become clear that constructing a single dimension that all research could agree upon is an insurmountable challenge due to the variations of existing definitions as outlined in this article.

\begin{tabular}{llll}
\hline $\begin{array}{l}\text { Article type: } \\
\text { Keywords: }\end{array}$ & $\begin{array}{l}\text { literature review, content analysis } \\
\text { virtual teams; team virtuality; definition; literature review; content analysis } \\
\text { JEL codes: }\end{array}$ & M10 & \\
\hline \multicolumn{1}{c}{ Received: 12 July 2017} & Revised: 2 August 2017 & Accepted: 20 October 2017 \\
\hline
\end{tabular}

\section{Suggested citation:}

Orhan, M.A. (2017). The Evolution of the Virtuality Phenomenon in Organizations: A Critical Literature Review. Entrepreneurial Business and Economics Review, 5(4), 171-188. http://doi.org/10.15678/EBER.2017.050408 


\section{INTRODUCTION}

Over the last two decades, we have been living in an increasingly connected society, where we interact with each other at a much higher frequency, even though we no longer need to meet face to face. Today, business organisations are those that benefit from the vast availability and accessibility of electronic communication tools; not only due to cost advantages, but also due to greater flexibility offered by these new technologies (Bell \& Kozlowski, 2002). To improve organisational performance and competitiveness, companies have started investing in virtual teams and related technologies (Ale Ebrahim, Ahmed, \& Taha, 2009). Advancements in communication technologies have also allowed organisations to reorganise their work structures by outsourcing tasks and workforces to another corner of the world for cheaper and easier labour (Janssen \& Joha, 2008; Curseu, Schalk, \& Wessel, 2008; Hertel, Geister, \& Konradt, 2005; Kirkman, Rosen, Tesluk, \& Gibson, 2004; Montoya-Weis, Massey, \& Song, 2001; Townsend, DeMarie, \& Hendrickson, 1998; Lipnack \& Stamps, 1997). The most common of these new work structures, "virtual teams" (VT), has now become an inseparable part of today's business world (Vartiainen, 2006). With this monumental development, a great deal of scholarly attention has been paid to virtual team research, quickly becoming one of the most popular topics in many different disciplines ranging from management to education, and from psychology to computer sciences. The different perspectives have contributed a very rich and diverse input on the design, processes, leadership and outcomes associated with team virtuality. It is believed that the majority of employees in multinational organisations take a role in a virtual team environment (Martins, Gilson, \& Maynard, 2004; Kanawattanachai \& Yoo, 2002). On the other hand, with the diversity of interdisciplinary approaches to the concept of "virtual teams", the meaning of "virtuality" is treated differently. The increased usage of information communication technology (ICT) tools in society have attracted researchers to explore online social relations, so that the term "virtual" has become a widespread phenomenon in social sciences. Mackenzie (2006) and Massumi (2002) oppose the idea of virtuality referring exclusively to ICT-mediated interactions or something that is related to the Internet. From a philosophical perspective, virtuality mainly refers to an abstract concept which signals temporality and distance to reality (Styhre, 2006). The semantic meaning of virtuality is thus closely linked to an approximation of real existence (Shields, 2006). Burt (2009) and Benson (2007) argue that the Internet, as a digital platform, connected virtual communities so online social relations attempt to replicate the real ones. However, the word "virtual" is commonly used interchangeably with other words referring to a state which involves either something that is online or related to a certain level of electronic communication and network, in addition to the Internet (Nyström \& Asproth, 2013; O'Keefe $\&$ Chen, 2011). The consequent ambiguity means that constructing a precise, comprehensive definition is even more difficult due to these different perspectives.

As of yet, there is still no universal understanding of what a virtual team is and how it should be defined (Gilson, Maynard, Young, Vartiainen, \& Hakonen, 2015). When virtual teams first emerged, they were considered merely to be temporary task forces assigned to particular, short-term projects (Lipnack \& Stamps, 1997, 1999; Jarvenpaa \& Leidner, 1999). Today, the virtuality concept has expanded from its initial definition in order to capture individual level, task-related virtualities in addition to team virtuality (Orhan, 2014; Orhan, Rijsman, \& van Dijk, 2016). While the novel approaches focus on a simplified measuring tool for the degree of virtuality (Hoch \& 
Kozlowski, 2014; Maynard, Mathieu, Rapp, \& Gilson, 2012), earlier measures based on older definitions are still widely in use in current research literature.

The literature also embraces a set of additional (and sometimes even conflicting) dimensions. Kimble (2011, p. 7) exemplifies the inconclusive characteristics between several existing definitions as follows:

The term virtual team can be applied to a number of different types of groups. Team membership may be relatively stable (e.g., in an established sales team) or change on a regular basis (e.g., in project teams). Members may be drawn from the same organization or from several different organizations (e.g., when projects involve consultants or external assessors). Team members may work in close proximity (e.g., in the same building) or geographically distantly (e.g., in different countries) and, similarly, team members may work at the same or at different times (e.g., depending on whether the team members are in the same time zone).

The goal of this article is to examine the variations of the existing dimensions of virtuality, and to determine common characteristics which can add clarity to the definition of it. Even though previous literature reviews enhanced the understanding of the implications brought about by virtual teams, this study differs from earlier studies in a number of ways. First, I argue that the concept of virtuality is a multidisciplinary phenomenon (de Guinea, Webster, \& Staples, 2012), whereas the majority of literature reviews narrowed their focus to a small number of disciplines and limited their review scope to the major business, management, information systems, psychology, and communications journals (Martins et al., 2004; Gibson \& Gibbs, 2006; Kirkman, Gibson, \& Kim, 2012). Virtual teaming is a term, as well as a common practice, widely used in fields as divergent as engineering, library sciences, computer sciences, cybernetics, education, economics and industrial relations. Therefore, this systematic review examines the issue of virtuality from a much broader perspective. Second, the methodology used in this article was purposely objective rather than restrictive. Unlike previous studies, articles were included in review regardless of the number of citations they received and the reputation of the journals which published them. Even to expand the scope further, EBSCO, $\mathrm{ABI} / \mathrm{INFORM}$ Global and Web of Science databases are utilised for an objective comparison. To observe trends and patterns of virtuality, the review years between 2006 and 2014 were analysed. These new results from the wider review range have underscored the necessity of solidifying a universal definition of virtuality. While this study lays definitions contained in the reviewed articles on the table, the proposed definition does not wipe the slate clean. Instead of creating additional confusion, this review aims to streamline the variations in the already existing definitions of virtual team research and summarise their common ground.

The article is structured in the following way: The subsequent section introduces the methodology of the article and the descriptive nature of the review. Findings of citation and content analysis are presented in the next section. Final sections include discussions, implications and limitations, as well as conclusion of this article.

\section{MATERIAL AND METHODS}

To find relevant articles about virtuality, the following search terms were used in the Web of Science, ABI/INFORM Global and EBSCO databases between 2006 and 2014: 
- "virtuality";

- "virtual team";

- "virtual teams";

- "virtualness";

- "virtual collaboration";

- "dispersed teams".

Based on the initial search results, 685 articles were collected from three databases. After several runs of manual and automated analyses, the duplicate articles, book reviews, conference and working papers, and other irrelevant titles (e.g. editorial notes) were removed, leaving 380 research articles. All of 380 articles were scanned based on the fact whether they included an operational or conceptual definition of virtuality. After scanning 380 articles, 115 were discarded, because 76 did not contain any definitions and 39 were found irrelevant. The number of usable articles for content and citation analyses was 265, as shown in Table 1.

Table 1. Number of articles found, scanned and reviewed by databases

\begin{tabular}{|l|c|c|c|}
\hline \multirow{2}{*}{ Databases } & \multicolumn{3}{c|}{ Articles } \\
\cline { 2 - 4 } & Reviewed & Scanned & No. of Search Results \\
\hline Web of Science & 118 & 154 & 234 \\
\hline EBSCO & 129 & 202 & 365 \\
\hline ABI/Inform Global & 18 & 24 & 86 \\
\hline Total & $\mathbf{2 6 5}$ & $\mathbf{3 8 0}$ & $\mathbf{6 8 5}$ \\
\hline
\end{tabular}

Source: own study.

Table 2 illustrates the number of articles per journal. The analyses carried out using the input from 173 journals, of which 45 included more than 1 article in their issues between the search period selected. This list includes the publications from various domains.

For the categorisation of the subject domains of journals, the classification information based on the fields assigned by each database was used. When there were more than two fields attributed, the highest two ranking domains were matched. When the domain information in the databases was not available, the journal's selfreported area of domain was recorded. According to the internal analysis, the highest number of research about virtual teams was conducted in the business/management domain with a total of 157 articles. Out of 157, there were 58 from the single domain of business/management journals. The second largest number of the articles reviewed was from the journals with multiple fields of business/management and psychology with 42 articles. The total number of articles with single domain was found as 145, while the remaining 120 articles came from multidisciplinary domains (combination of two different domains). These results prove the multidisciplinary perspective of virtuality in teams in general. The number of articles reviewed per domain is presented in Table 3. Diagonals in the table refer to the number of articles which are published in a single discipline journal. Other figures in the table represent the number of journals combining two different disciplines. 
Table 2. Journals and number of published articles reviewed

\begin{tabular}{|c|c|}
\hline Name of the Journal & No. of Articles Reviewed \\
\hline IEEE Transactions on Professional Communication & 11 \\
\hline Computers in Human Behaviour & 8 \\
\hline Team Performance Management & 8 \\
\hline Small Group Research & 8 \\
\hline International Journal of E-Collaboration & 5 \\
\hline Journal of Management Information Systems & 5 \\
\hline Group Decision and Negotiation & 5 \\
\hline International Journal of Project Management & 5 \\
\hline Journal of Information Science & 3 \\
\hline Information Systems Journal & 3 \\
\hline Information \& Management & 3 \\
\hline Behaviour \& Information Technology & 3 \\
\hline Journal of Information \& Knowledge Management & 3 \\
\hline Group \& Organization Management & 3 \\
\hline Gruppendynamik und Organisationsberatung & 3 \\
\hline Journal of Product Innovation Management & 3 \\
\hline Journal of Leadership \& Organizational Studies & 2 \\
\hline Journal of Computer-Mediated Communication & 2 \\
\hline Human Factors \& Ergonomics in Manufacturing & 2 \\
\hline African Journal of Business Management & 2 \\
\hline Communications of the ACM & 2 \\
\hline Expert Systems with Applications & 2 \\
\hline Journal of Managerial Psychology & 2 \\
\hline Global Business \& Organizational Excellence & 2 \\
\hline Journal of Computer Information Systems & 2 \\
\hline Information Technology \& People & 2 \\
\hline Journal of General Management & 2 \\
\hline Journal of Personnel Psychology & 2 \\
\hline European Journal of Engineering Education & 2 \\
\hline Journal of the Association for Information Systems & 2 \\
\hline Journal of Management Education & 2 \\
\hline Leadership Quarterly & 2 \\
\hline Journal of Organizational Behavior & 2 \\
\hline MIS Quarterly & 2 \\
\hline Organizational Behavior \& Human Decision Processes & 2 \\
\hline International Journal of Cross Cultural Management & 2 \\
\hline Knowledge Management Research \& Practice & 2 \\
\hline American Journal of Business & 2 \\
\hline Management Research News & 2 \\
\hline Quarterly Review of Distance Education & 2 \\
\hline Organization Science & 2 \\
\hline Revista de Psicologia del Trabajo y de Las Organizaciones & 2 \\
\hline Proceedings of World Academy of Science: Engineering \& Technology & 2 \\
\hline The DATA BASE for Advances in Information Systems & 2 \\
\hline Project Management Journal & 2 \\
\hline Other Journals with 1 article & 128 \\
\hline Total & 265 \\
\hline
\end{tabular}

Source: own study. 
Table 3. Number of reviewed articles by domain of the journals

\begin{tabular}{|l|c|c|c|c|c|c|c|c|}
\hline \multicolumn{1}{|c|}{ Domain } & $(\mathbf{1})$ & $\mathbf{( 2 )}$ & $\mathbf{( 3 )}$ & $\mathbf{( 4 )}$ & $\mathbf{( 5 )}$ & $\mathbf{( 6 )}$ & $\mathbf{( 7 )}$ & Total \\
\hline (1) Business/Management & 58 & & & & & & & \\
\hline (2) Information Systems & 33 & 25 & & & & & & \\
\hline (3) Communication/Media Studies & 3 & 4 & 14 & & & & & \\
\hline (4) Psychology & 42 & - & - & 11 & & & & \\
\hline (5) Education & 4 & 2 & - & - & 9 & & & \\
\hline (6) Computer Science & - & - & - & - & - & 6 & & \\
\hline (7) Others* & 17 & 7 & 1 & 3 & 3 & - & 23 & \\
\hline
\end{tabular}

* Others include the following categories: Social Sciences, Engineering, Economics, Planning and Development, Ergonomics, Applied Sciences, Sociology, Medicine, Public Relations, Philosophy, Cultural Studies, Statistics, Industrial and Labour Relations

Source: own study.

\section{LITERATURE REVIEW AND THEORY DEVELOPMENT}

\section{Citation Analysis}

For the citation analysis, the definition of virtuality in each of 265 articles was recorded. Out of 265, 152 articles (57.36\%) used at least one cited reference for its definition. It is found that researchers of these 152 articles used past sources of 249 articles when citing the definition of virtuality. The remaining 113 articles (42.64\%) either provided no reference or reported a definition that was based on a self-constructed novel discussion. Table 4 below presents the most frequently cited references.

Table 4. Most frequently cited references

\begin{tabular}{|c|c|c|c|}
\hline $\begin{array}{c}\text { Cited Reference for } \\
\text { Virtuality Definition }\end{array}$ & $\begin{array}{c}\text { No. of Articles } \\
\text { Citing }\end{array}$ & $\begin{array}{c}\text { Cited Reference for } \\
\text { Virtuality Definition }\end{array}$ & $\begin{array}{c}\text { No. of Articles } \\
\text { Citing }\end{array}$ \\
\hline Martins et al., 2004 & 17 & Kirkman \& Mathieu, 2005 & 7 \\
\hline Jarvenpaa \& Leidner, 1999 & 17 & Gibson \& Cohen, 2003 & 4 \\
\hline Lipnack \& Stamps, 2000 & 14 & Malhotra, Majchrzak, \& Rosen, 2007 & 4 \\
\hline Powell, Piccoli, \& Ives, 2004 & 13 & Jarvenpaa \& Leidner, 1998 & 4 \\
\hline Bell \& Kozlowski, 2002 & 12 & Mowshowitz, 1997 & 3 \\
\hline Townsend et al., 1998 & 11 & Griffith \& Neale, 2001 & 3 \\
\hline Hertel et al., 2005 & 10 & Cohen \& Gibson, 2003 & 3 \\
\hline Lipnack \& Stamps, 1997 & 9 & Lipnack \& Stamps, 1999 & 3 \\
\hline Maznevski \& Chudoba, 2000 & 9 & Kirkman et al., 2004 & 3 \\
\hline
\end{tabular}

Source: own study.

The mostly cited references included the definitions of the same authors' earlier contributions. The definitions form Lipnack and Stamps's three studies (2000, 1999 and 1997) were cited in 26 later studies reviewed. Similarly, both works of Jarvenpaa and Leidner (1999, 1998) were referenced in 21 articles collectively. Finally, the direct definitions of Gibson and Cohen (2003) and Cohen and Gibson (2003) received a total of seven mentions in the reviewed articles. For establishing a foundation built on previous research, the direct quotes most frequently used in defining virtual teams and subsequently virtuality are presented in 
Table 5. There are a total of 12 studies which are relatively popular, constituting $49.43 \%$ of the definitions used in the reviewed articles. The direction of literature has gone beyond the dichotomous view of virtual teams vs. traditional teams to a continuum of team virtuality (Dixon \& Panteli, 2010). The earlier literature contains definitions from both perspectives. Therefore, in Table 5, the defined concept is explicitly specified.

Most articles reviewed in this study argue that virtuality in teams is linked to corporal characteristics of teams. In this regard, the majority of the cited definitions demonstrate the physical aspects of virtuality that are linked to content related aspects such as geographic/organisational dispersion, information technology use or lack of face-to-face communication. Nevertheless, the definition proposed by Kirkman and Mathieu (2005) added a seminal knowledge to the literature related to the process related aspect of virtuality; the amount of informational value, shared via computer mediated interactions, and the synchronicity of virtual interactions within the team environment. According to this definition, the extent of the use of electronic communication tools is not the only warrant of a high degree of virtuality. The impact of the frequent use of electronic tools, and therefore the extent of virtuality is much higher when the value of information is higher and information sharing takes place in less synchronous conditions. The characteristics of task structures play an important role in determining the level of team virtuality. Teams that accomplish tasks which require higher team interdependence will be considered more virtual, if information is exchanged over electronic tools with asynchronous modes of communication.

Table 5. Most cited definitions

\begin{tabular}{|l|c|l|}
\hline $\begin{array}{l}\text { Authors, Year } \\
\text { (page no) }\end{array}$ & $\begin{array}{c}\text { Concept } \\
\text { defined }\end{array}$ & \multicolumn{1}{c|}{ Definition } \\
\hline $\begin{array}{l}\text { Martins et al., } \\
\begin{array}{l}2004 \\
\text { (p. 808) }\end{array}\end{array}$ & VT & $\begin{array}{l}\text { "whose members use technology to varying degrees in working across } \\
\text { locational, temporal, and relational boundaries to accomplish an inter- } \\
\text { dependent task" }\end{array}$ \\
\hline $\begin{array}{l}\text { Jarvenpaa \& } \\
\text { Leidner, 1999 } \\
\text { (p. 792); 1998 }\end{array}$ & $\begin{array}{c}\text { Global } \\
\text { VT }\end{array}$ & $\begin{array}{l}\text { "temporary, culturally diverse, geographically dispersed, electronically } \\
\text { communicating work group" }\end{array}$ \\
\hline $\begin{array}{l}\text { Lipnack \& } \\
\text { Stamps, 2000 } \\
\text { (p. 18) }\end{array}$ & VT & $\begin{array}{l}\text { "a group of people who work interdependently with a shared purpose } \\
\text { across space, time, and organizational boundaries using technology" }\end{array}$ \\
\hline $\begin{array}{l}\text { Powell et al., } \\
\begin{array}{l}2004 \\
\text { (p. 7) }\end{array}\end{array}$ & VT & $\begin{array}{l}\text { "groups of geographically, organizationally and/or time dispersed } \\
\text { worker brought together by information and telecommunication tech- } \\
\text { nologies to accomplish one or more organizational tasks" }\end{array}$ \\
\hline $\begin{array}{l}\text { Bell \& Ko- } \\
\text { zlowski, 2002 } \\
\text { (p. 25) }\end{array}$ & VT & $\begin{array}{l}\text { "the key characteristics of virtual teams that distinguish them from } \\
\text { conventional teams are } \\
\text { (a) the spatial distance between team members that restricts face-to- } \\
\text { face communication and } \\
\text { (b)the resulting use of technological communication to connect team } \\
\text { members" }\end{array}$ \\
\hline $\begin{array}{l}\text { Townsend et } \\
\text { al., 1998 } \\
\text { (p. 17) }\end{array}$ & VT & $\begin{array}{l}\text { "groups or geographically and/or organizationally dispersed coworkers } \\
\text { that are assembled using a combination of telecommunications and in- } \\
\text { formation technologies to accomplish an organizational task" }\end{array}$ \\
\hline
\end{tabular}




\begin{tabular}{|c|c|c|}
\hline $\begin{array}{c}\text { Authors, Year } \\
\text { (page no) }\end{array}$ & $\begin{array}{l}\text { Concept } \\
\text { defined }\end{array}$ & Definition \\
\hline $\begin{array}{l}\text { Hertel et al. } \\
(2005, \text { p. } 71)\end{array}$ & VT & $\begin{array}{l}\text { "consists of (a) two or more persons who (b) collaborate interactively } \\
\text { to achieve common goals, while (c) at least one of the team members } \\
\text { works at a different location, organization, or at a different time so } \\
\text { that (d) communication and coordination is predominantly based on } \\
\text { electronic communication media" }\end{array}$ \\
\hline $\begin{array}{l}\text { Lipnack \& } \\
\text { Stamps (1997) }\end{array}$ & VT & $\begin{array}{l}\text { "unlike conventional teams, a virtual team works across space, time, } \\
\text { and organizational boundaries with links strengthened by webs of com- } \\
\text { munication technologies" }\end{array}$ \\
\hline $\begin{array}{l}\text { Maznevski \& } \\
\text { Chudoba } \\
(2000, \text { p. } 473 \\
\text { and p. } 474)\end{array}$ & $\begin{array}{l}\text { Global } \\
\text { VT }\end{array}$ & $\begin{array}{l}\text { "internationally distributed groups of people with an organizational } \\
\text { mandate to make or implement decisions with international compo- } \\
\text { nents and implications. They are typically assigned tasks that are stra- } \\
\text { tegically important and highly complex" \& } \\
\text { "Kristof et al. (1995) and Jarvenpaa and Leidner (1998) describe global } \\
\text { virtual teams as culturally diverse and geographically dispersed. We } \\
\text { add that global virtual teams are also global in their task" }\end{array}$ \\
\hline $\begin{array}{l}\text { Kirkman \& } \\
\text { Mathieu } \\
(2005 \\
\text { p. } 702)\end{array}$ & $\begin{array}{c}\text { Team } \\
\text { Virtuality }\end{array}$ & $\begin{array}{l}\text { "[is defined] using three dimensions: } \\
\text { (a) the extent to which team members use virtual tools to coordinate } \\
\text { and execute team processes (including communication media such as } \\
\text { e-mail and videoconferencing and work tools such as group decision } \\
\text { support systems, } \\
\text { (b) the amount of informational value provided by such tools, and (c) } \\
\text { the synchronicity of team member virtual interaction." }\end{array}$ \\
\hline $\begin{array}{l}\text { Gibson \& Co- } \\
\text { hen }(2003 \text {, } \\
\text { p. } 4)\end{array}$ & $\begin{array}{c}\text { Team } \\
\text { Virtuality }\end{array}$ & $\begin{array}{l}\text { "To be considered virtual to some degree, a team must have the follow- } \\
\text { ing three attributes: } \\
\text { - It is a functioning team-a collection of individuals who are interde- } \\
\text { pendent in their tasks, share responsibility for outcomes, see them- } \\
\text { selves and are viewed by others as an intact social unit embedded in } \\
\text { one or more social systems, and collectively manage their relationships } \\
\text { across organizational boundaries (Hackman, 1987; Alderfer, 1977)*. } \\
\text { - The members of the team are geographically dispersed. } \\
\text { - The team relies on technology-mediated communications rather than } \\
\text { face-to-face interaction to accomplish their tasks." }\end{array}$ \\
\hline $\begin{array}{l}\text { Malhotra et al. } \\
(2007, \text { p. 60) }\end{array}$ & VT & $\begin{array}{l}\text { "whose members are geographically distributed, requiring them to } \\
\text { work together through electronic means with minimal, or in extreme } \\
\text { circumstances, no face-to-face interaction" }\end{array}$ \\
\hline
\end{tabular}

Source: own study.

Even though the normative theory of science acknowledges that the contribution of past research within a certain field can be measured best by analysing the citing behaviour of researchers, social constructivist theory, on the other hand, argues that citation analysis is not the best way to illustrate the theoretical development of a concept, because concepts socially evolve over time (Serenko \& Dumay, 2015). Moreover, past research delivers evidence that authors are prone to cite studies that are published by well-known researchers or in reputable journals, which are not necessarily scientifically and theoretically the most reflective ones (de Villiers \& Dumay, 2013). To overcome the biased inclination of citing behaviour, content analysis is considered a sensible way to objectively analyse social 
constructs. Therefore, to understand the underlying concepts and latent relations between social constructs, it may be imperative to conduct a content analysis. In the next section, the details and results of the content analysis are presented.

\section{Content Analysis}

In addition to the citation analysis which examines the most cited studies in the virtuality research, a separate content analysis is conducted to review the qualitative nature of the dataset. The main benefit of using a content analysis is that the deductive approach allows researchers to observe the directions and trends of research over time. Systematic coding makes content analysis a powerful tool due to improved replicability (Stemler, 2001). For all articles reviewed, author information, publication information, defined concept and selected definitions were recorded. A sample of coding is illustrated below (Table 6). Before moving to coding, all definitions and dimensions were copied separately. All reviews, checks and coding were made manually. For improved accuracy, the articles were reviewed twice in order not to skip any definition cited in the reviewed articles, and coded accordingly. Labels of coding are exhibited in Table 7. Those labels were created based on the dimensions or characteristics defined.

Table 6. Sample coding

\begin{tabular}{|c|c|c|c|}
\hline $\begin{array}{c}\text { Authors, Year } \\
\text { (page no) }\end{array}$ & $\begin{array}{l}\text { Concept } \\
\text { defined }\end{array}$ & $\begin{array}{c}\text { Operational / Theoretical } \\
\text { Definitions }\end{array}$ & Coding* \\
\hline $\begin{array}{l}\text { Martins et al., } \\
2004 \text { (p. 808) }\end{array}$ & VT & $\begin{array}{l}\text { "whose members use technology to varying degrees in } \\
\text { working across locational, temporal, and relational } \\
\text { boundaries to accomplish an interdependent task" }\end{array}$ & $\begin{array}{l}\text { ICT, GD, } \\
\text { TD, RB, } \\
\text { INTT }\end{array}$ \\
\hline $\begin{array}{l}\text { Schiller \& } \\
\text { Mandviwalla, } \\
2007 \text { (p. 13) }\end{array}$ & VT & $\begin{array}{l}\text { "(a) Members interact through interdependent tasks } \\
\text { guided by common purposes (Lipnack \& Stamps, 1997), } \\
\text { (b) they use CMC or telecommunication media substan- } \\
\text { tially more than face-to-face communication (Anawati } \\
\text { \& Craig, 2006; Fiol \& O'Connor, 2005; } \\
\text { Griffith \& Neale,2001), and } \\
\text { (c) they are geographically dispersed from each other } \\
\text { (Cohen \& Gibson, 2003; Griffith \& Meader, 2004)." }\end{array}$ & $\begin{array}{l}\text { ICT, GD, } \\
\text { MF2F, } \\
\text { INTT }\end{array}$ \\
\hline $\begin{array}{l}\text { Schweitzer \& } \\
\text { Duxbury, } 2010 \\
\text { (p. 272) }\end{array}$ & VT & $\begin{array}{l}\text { "In our opinion, geographic dispersion should be suffi- } \\
\text { cient to warrant the term virtual team." }\end{array}$ & GD \\
\hline Guo et al., 2009 & VT & $\begin{array}{l}\text { "groups of people engaged in a common organizational } \\
\text { task through electronic information and communication } \\
\text { technologies." }\end{array}$ & ICT \\
\hline
\end{tabular}

* Refer to Table 7 for the coded dimensions.

Source: own study.

The content analysis in this article starts with shedding light on the descriptive nature of virtuality characteristics. When defining virtuality, a total number of 779 dimensions were used in 265 studies. This indicates that the mean number of dimensions used in a single definition was 2.95 with a 1.40 standard deviation. Out of 265 articles, 83 reported a definition that is composed of two dimensions. Although a single dimension was sufficient for 33 studies (12.45\%), as many as nine separate dimensions for one definition were 
encountered. Table 8 shows the details of the frequency statistics of dimensions used in a single definition. The numbers in parenthesis identify the number of articles which cited the dimension in question as a single defining characteristic of virtuality.

Table 7. Labels of coding

\begin{tabular}{|c|c|c|}
\hline Code & Labels & Including \\
\hline ICT & $\begin{array}{l}\text { ICT mediated interac- } \\
\text { tion }\end{array}$ & electronic communication, \\
\hline GD & Geographic dispersion & $\begin{array}{l}\text { spatial dispersion, } \\
\text { locational dispersion, } \\
\text { different locations, etc. }\end{array}$ \\
\hline TD & Temporal dispersion & $\begin{array}{l}\text { time dispersion, } \\
\text { time-zone differences }\end{array}$ \\
\hline OD & $\begin{array}{l}\text { Organisational disper- } \\
\text { sion }\end{array}$ & different organisational membership \\
\hline MF2F & $\begin{array}{l}\text { Minimal face-to-face- } \\
\text { contact }\end{array}$ & $\begin{array}{l}\text { rare } \mathrm{f} 2 \mathrm{f} \text { meetings, } \\
\text { limited encounters }\end{array}$ \\
\hline INTT & Interdependent tasks & interdependent group \\
\hline $\mathrm{CD}$ & Cultural diversity & cultural dispersion \\
\hline TL & Temporary lifespan & $\begin{array}{l}\text { temporary membership, } \\
\text { no future }\end{array}$ \\
\hline LF2F & $\begin{array}{l}\text { Lack of face-to-face- } \\
\text { contact }\end{array}$ & $\begin{array}{l}\text { no physical contact, } \\
\text { lack of personal contact, } \\
\text { no chance to contact } f 2 f\end{array}$ \\
\hline RB & Relational boundaries & $\begin{array}{l}\text { no social cues, } \\
\text { limited context cues }\end{array}$ \\
\hline INDT & Independent tasks & $\begin{array}{l}\text { independent individuals, } \\
\text { no task coordination required }\end{array}$ \\
\hline ID & $\begin{array}{l}\text { International disper- } \\
\text { sion }\end{array}$ & $\begin{array}{l}\text { different countries, } \\
\text { worldwide dispersion }\end{array}$ \\
\hline ND & National dispersion & $\begin{array}{l}\text { diverse in national culture, } \\
\text { cultural dispersion }\end{array}$ \\
\hline SYNC & Synchronicity & $\begin{array}{l}\text { (a)synchronicity, } \\
\text { simultaneous work processes, asynchronous responses, asyn- } \\
\text { chronous communication }\end{array}$ \\
\hline $\mathrm{NH}$ & No previous history & no past \\
\hline PW & Project work & \\
\hline
\end{tabular}

Source: own study.

The analysis further revealed that 229 of 265 articles (86.42\%) treated ICT-mediated interaction as the major defining characteristic of virtuality. Out of these, 21 considered ICTmediated interactions as the only determinant of virtuality, as they refer to no other related dimension. In nine studies, geographic dispersion (GD) was the only characteristic that distinguishes virtuality from traditional settings. GD was thus found to be another major dimension that characterises virtuality. A total of 208 articles (78.49\%) used GD as a distinctive feature of virtuality, whereas three studies using a single dimension considered face-to-face contact to be the defining factor. Minimal face-to-face contact (MF2F) was used in 45 (16.98\%) and lack of face-to-face contact (LF2F) was used in 22 articles (8.30\%). Temporal 
dispersion (TD) and organisation dispersion (OD) dimensions were among those very highly referred to, although only one article considers temporal dispersion as a stand-alone characteristic. TD is used as a typical construct in 75 cases (28.30\%), whereas OD is used in 58 cases $(21.89 \%)$. In addition to the listed dimensions, "others" include "simultaneous work processes," "knowledge intensive," "information value," "process informatisation," "technology dispersion," "complex tasks,", "agilities in functions, workplaces, competencies, work contracts, equipment, functional dependencies, and hierarchical dependencies".

Table 8. Frequency table of dimensions used in definitions

\begin{tabular}{|c|c|c|c|}
\hline Dimension* & $\begin{array}{c}\text { Total Frequency of } \\
\text { Dimensions used in } \\
\text { Definitions }\end{array}$ & Dimension & $\begin{array}{c}\text { Total Frequency of } \\
\text { Dimensions used in } \\
\text { Definitions }\end{array}$ \\
\hline ICT & $229(21)$ & RB & 14 \\
\hline GD & $208(9)$ & SYNC & 7 \\
\hline TD & $75(1)$ & NH & 6 \\
\hline OD & 58 & ID & 4 \\
\hline MF2F & $45(2)$ & NDDT & 4 \\
\hline INTT & 41 & PW & 4 \\
\hline LF2F & $23(1)$ & LD & 2 \\
\hline CD & 20 & Others & 19 \\
\hline$T L$ & 17 & \multicolumn{2}{l}{} \\
\hline & \multicolumn{2}{|c|}{ Total Count of Dimensions: 779} & \\
\hline
\end{tabular}

* Refer to Table 7 for the coded dimensions.

Source: own study.

As there are many dimensions considered vital to varying degrees, it is essential to visualise how these dimensions are incorporated to formulate a preferred definition. To begin, four most frequently used dimensions were selected; ICT use, geographic dispersion, temporal dispersion and organisational dispersion. These particular dimensions were put under the microscope because there were 570 uses versus the total number of dimensions used, which is 779 . With the Venn diagram in Figure 1 , each dimension is presented as a unique set, where the numbers in the intersections denote the number of studies using the specific dimension.

The definitions which incorporate both ICT use and geographic dispersion have the highest occurrences in this review: 178. On the other hand, 102 cases included both geographic dispersion and ICT usage but they concluded that neither temporal dispersion nor organisational dispersion is a distinctive determinant that typifies virtuality. However, 34 articles reach the conclusion that both temporal dispersion and organisational dispersion are required when ICT usage and geographic dispersion are present in virtuality.

Even though Martins et al. (2004), as one of the most commonly cited references in virtuality research, asserted that geographic dispersion is the most commonly noted dimension, this content analysis revealed that the emphasis on geographic dispersion was succeeded by ICT-mediated interactions. This finding confirms with the studies of Cohen and Gibson (2003), Gibson and Gibbs (2006), Stanko and Gibson (2009) and Gilson et al. (2015) which argued that geographic dispersion, coupled with ICT-mediated interactions, were the most frequently attributed characteristics of virtuality. 


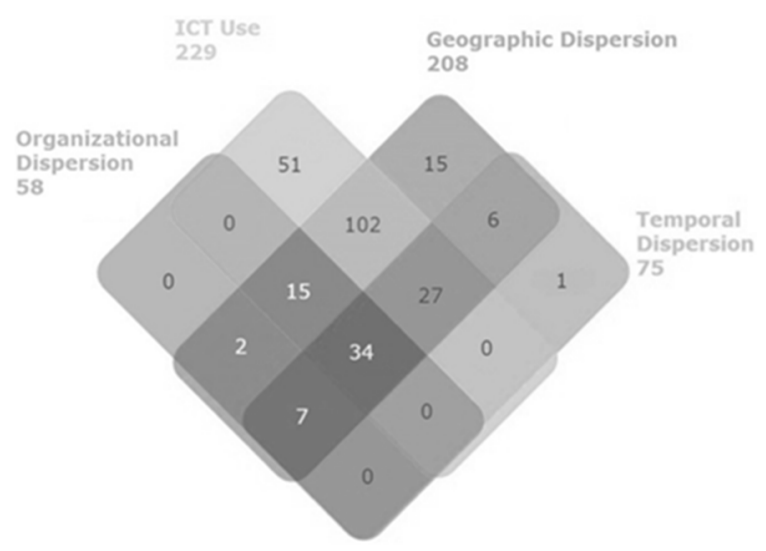

Figure 1. Venn diagram of most frequently used dimensions in definitions Source: own elaboration.

Another iteration of Venn diagram (Figure 2) was formulated in order to assess the impact of F2F contact dimension after leaving out temporal and organisation dispersion. The reason is twofold. First, in the reviewed articles, the operational definition of virtuality was based on the lack of F2F contact, even when high ICT use and geographic dispersion were cited. Second, when the measurement of virtuality in the empirical studies was examined, the assessment of the extent of F2F contact was more common. The analyses also revealed that out of the 178 articles containing both ICT and GD dimensions, 42 cases report lack or minimal face-to-face contact as the most defining characteristic. Of 265 studies, the extent of virtuality was measured in 94 studies (35.47\%). Among these 94 studies, 78 (82.98\%) either utilised the degree of face-to-face communication in their virtuality measures or assessed face-to-face interactions as a control variable in the studies. This illustrates that the extent of face-to-face communication (or the lack thereof) determines the degree of virtuality, even though its presence in theoretical definitions is found to be less frequent.

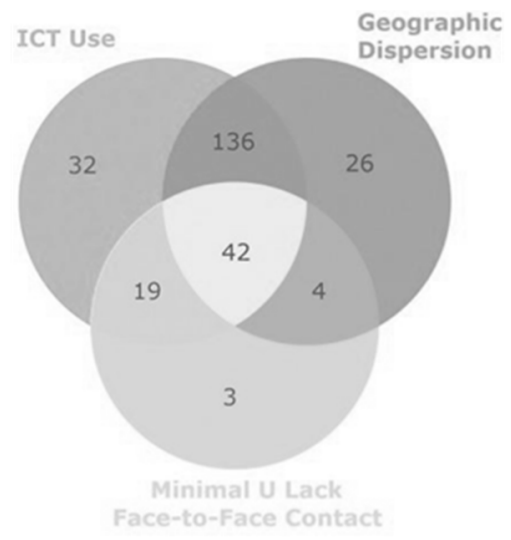

Figure 2. Venn diagram: ICT \& geographic dispersion \& minimal face-to-face contact Source: own elaboration. 
Based on the content analyses presented in this section, the discussions section addresses the research questions set out in the introduction. The findings of these citation and content analyses have suggested evidence how virtuality can be defined and measured. The majority of defining characteristics include the dependence on ICT use, the spatial dispersion of team members, and the extent of face-to-face communication. Often these dimensions are used collectively to define the virtuality concept. On the other hand, the use of single dimension for defining virtuality is not rare, either. With these findings, this study also renders how virtual team research has been evolving over the last few years, especially after virtuality has been considered to be a multifaceted construct. In the next section, the interplay between these dimensions is elaborated in addition to the implications and limitations.

\section{DISCUSSION}

There has been a growing body of literature on virtual team research over the last 20 years. The existing research includes both empirical studies and theoretical approaches. However, it is often argued that the vastness of this empirical research has overshadowed the theoretical foundation and conceptualisation required to understand what virtuality really means (Martins et al., 2004). This resulted in a long list of items that proved to be of little practical value, or was irrelevant for the understanding of team virtuality (Maynard \& Gilson, 2013; Hakonen \& Lipponen, 2008; Gibson \& Gibbs, 2006; Chudoba, Wynn, Lu, \& Watson-Manheim, 2005; Kirkman \& Mathieu, 2005). Even though some scholars claimed that a minimum level of consensus had been reached in defining a virtual team (Johnson Bettenhausen, \& Gibbons, 2009; de Leede, Kraan, den Hengst, \& van Hooff, 2008), this study has shown that the literature is loaded with many different (and sometimes even conflicting) dimensions.

In spite of the polarisation of research in defining what virtuality actually means, the results may reflect that some level of consensus is still achievable. In the organisational context, the attainment of team tasks is achieved in real terms without the physical formation of a team. A team is still a functioning social system (Curseu, 2006), but as these systems' achievements are highly dependent on information exchange through electronic communication, the large body of the literature considers virtual equal to digital (Mackenzie, 2006; Massumi, 2002). As the Internet provided a digital platform and connected virtual communities, online social relations functioned as well as if they were real (Burt, 2009; Benson, 2007). As a result, with the increased usage of information communication technology tools, the term "virtual" has become a widespread phenomenon that attracted researchers in social sciences to explore the social relations occurring online. There are also other alternative approaches to describing virtuality. Although these early examples of virtual work show that the virtual team phenomenon is not a new concept, its theoretical conceptualisation, evolution and widespread implementation in business context does have a relatively short history. New technologies, which allowed for synchronous communication at a cheaper and faster rate, enabled more flexible and versatile structures in the last decades. The dominant approach to the current state of virtual teams, therefore, is that virtual teams are virtual due to the high dependence on information communication tools and technologies. However, under the light of review findings, I argue that the dependence might be the consequence of lack of (or barriers to) face-to-face communication. One of the reasons for barriers might be geographic dispersion, but the lack of face-to-face communication can also be a preferred choice. So, virtual teams are virtual; not because of high ICT usage, but 
because of the lack of face-to-face communication possibilities or because of preferences. Thus, the theoretical contribution of this study is to broaden the definitions of virtual teams by removing both geographic dispersion and dependency on the electronic communication and information technologies elements. The analyses also show that while the existing definitions propose multiple dimensions, including geographic temporal, organisational dispersion, electronic communication, task interdependence, or even cultural diversity, the measurement of virtuality often requires fewer dimensions. It confirms with Martins et al. (2004) that the operational definition differs from the theoretical propositions. It would be more appropriate to define virtual teams as any team that does not communicate face-to-face to accomplish team tasks. This definition also enables the coherence between the measurement and conceptualisation. The differences of communication methods other than ICT tools, and geographic dispersion can moderate the impacts of virtuality.

Recently, the need for unity and cohesion in quantifying virtuality measurement has been cited in the literature by Gilson et al. (2015). This is considered as particularly important because how operational definition is conceptualised determines the choice of virtuality measurement (e.g. the extent of ICT use or geographical distance between members). These variations can impose different implications if there is no unity and consistency in measurements. In this study, I have shown that the majority of reviewed articles either utilised the degree of face-to-face communication in virtuality measurements or assessed the level of face-to-face interactions as a control variable in the studies to determine the impact on virtuality. This illustrates that the extent of face-to-face communication (or the lack thereof) determines the degree of virtuality, even though its presence in theoretical definitions is found to be less frequent. As a result, one can argue that researchers studying virtuality are in agreement with the fact that face-to-face communication is one of the most significant defining factors of virtuality.

However, as many others, this study does not come without its limitations. As the sole author of this article, I recognise the fact that the reliability of this study could have been improved with a secondary coder in order to measure inter-coder reliability, which is considered as crucial for content analyses. However, considering the purpose of this review, the data and findings can still be considered reliable since the content and citation analyses rely on a straightforward method, as discussed in the methodology section.

Another limitation can be related to the selection of academic databases. The data was obtained from prominent, mainstream social sciences databases. With open access journals becoming more popular, there is a growing trend toward publishing with them and, in turn, respect for online journals within the scholarly community is slowly gaining momentum (Acharya, Verstak, Suzuki, Henderson, lakhiaev, Lin, \& Shetty, 2014). Although this review is one of the most extensive studies on virtual teams, inclusion of other databases could broaden the picture. For future research, scholars can include additional years and databases to track the changes in the virtuality research to understand the direction of conceptualisation.

\section{CONCLUSIONS}

Given the extensive nature of the literature review covering the years between 2006 and 2013 , the citation and content analyses presented here exhibited the varying treatment of definitions of virtuality in the literature. After considering different approaches and dimensional constructs, in addition to variations in the same dimensions, it has become clear 
that constructing a single dimension that all research could agree upon is an insurmountable challenge due to the variations of existing definitions as outlined in this article. But determining the common ground for virtuality measurement is a matter of urgency. A unified means of measuring, however, could only be developed by isolating the dimension shared by all of the definitions: the extent of face-to-face communication. However, the impacts of other dimensions cited for defining virtuality should also guide researchers to determining the moderating and mediating impacts of virtuality.

This study examined how the number of dimensions and boundaries defined in the literature varies significantly. Consequently, only a limited number of studies defined virtuality as deriving primarily from the lack of face-to-face interaction in physical settings. Geographic dispersion and ICT may be the causes of not being able to meet faceto-face, but they do not axiomatically mean that team members perpetually fail to meet face-to-face in order to complete their tasks. Any team can score high on a virtuality scale without being geographically dispersed and without using ICT. All it takes is for team members not to see each other. From the practical point of view, in order to increase competitiveness, researchers and practitioners may need to understand both the advantages and disadvantages of the lack of face-to-face interactions in organisations, as new forms of doing work make virtually everyone virtual.

\section{REFERENCES}

Acharya, A., Verstak, A., Suzuki, H., Henderson, S., lakhiaev, M., Lin, C.C.Y., \& Shetty, N. (2014). Rise of the rest: The growing impact of non-elite journals. CoRR: arXiv preprint arXiv:1410.2217, doi: 10.1111/ecoj.12254

Ale Ebrahim, N., Ahmed, S., \& Taha, Z. (2009). Virtual teams: A literature review. Australian Journal of Basic and Applied Sciences, 3(3), 2653-69.

Bell, B.S., \& Kozlowski, S.W.J. (2002). A typology of virtual teams: Implications for effective leadership. Group \& Organization Management, 27, 14-49.

Benson, O. (2007). The rise of the blogger. The Philosophers Magazine, 37(1), 12-14.

Burt, K. (2009). The Internet: Proposing an infrastructure for the philosophy of virtualness. Techne: Research in Philosophy \& Technology, 13(1), 50-68.

Chudoba, K.M., Wynn, E., Lu, M., \& Watson-Manheim, M.B. (2005). How virtual are we? Measuring virtuality and understanding its impact in a global organization. Information Systems Journal, 15, 279-306.

Cohen, S.G., \& Gibson, C.B. (2003). In the beginning: Introduction and framework. In C.B. Gibson \& S.G. Cohen (Eds.), Virtual teams that work: Creating conditions for virtual team effectiveness (pp. 1-13). San Francisco: Jossey-Bass.

Curseu, P.L. (2006). Emergent states in virtual teams: A complex adaptive systems perspective. Journal of Information Technology, 21(4), 249-261.

Curseu P.L., Schalk, R., \& Wessel, I. (2008). How do virtual teams process information? A literature review and implications for management. Journal of Managerial Psychology, 23(6), 628-652.

de Guinea, A.O., Webster, J., \& Staples, D.S. (2012). A meta-analysis of the consequences of virtualness on team functioning. Information \& Management, 49(6), 301-308.

de Villiers, C., \& Dumay, J. (2013). Construction of research articles in the leading interdisciplinary accounting journals. Accounting, Auditing \& Accountability Journal, 26(6), 876-910.

Dixon, K.R., \& Panteli, N. (2010). From virtual teams to virtuality in teams. Human Relations, 63(8), 1177-1197. 
Duarte, D.L., \& Snyder, N.T. (1999). Mastering virtual teams: Strategies, tools, and techniques that succeed. San Francisco, CA: Jossey-Bass.

Gibson, C.B., \& Cohen, S.G. (2003). Virtual teams that work: Creating conditions for virtual team effectiveness. San Francisco, CA: Jossey-Bass.

Gibson, C.B., \& Gibbs, J.L. (2006). Unpacking the concept of virtuality: The effects of geographic dispersion, electronic dependence, dynamic structure, and national diversity on team innovation. Administrative Science Quarterly, 51(3), 451-495.

Gilson, L.L., Maynard, M.T., Young, N.C.J., Vartiainen, M., \& Hakonen, M. (2015). Virtual teams research: 10 years, 10 themes, and 10 opportunities. Journal of Management, 41(5). 1313-1337.

Griffith, T.L., \& Neale, M.A. (2001). Information processing in traditional, hybrid, and virtual teams: From nascent knowledge to transactive memory. In B.M. Staw \& R.L. Sutton (Eds.), Research in Organizational Behavior (vol. 23, pp. 379-421). Greenwich, CT: JAI Press.

Guo, Z., D’Ambra, J., Turner, T., \& Zhang, H. (2009). Improving the effectiveness of virtual teams: A comparison of video-conferencing and face-to-face communication in China. IEEE Transactions on Professional Communication, 52(1), 1-16.

Hakonen, M., \& Lipponen, J. (2008). Procedural justice and identification with virtual teams: The moderating role of face-to-face meetings and geographical dispersion. Social Justice Research, 21(2), 164-178.

Hertel, G., Geister, S., \& Konradt, U. (2005). Managing virtual teams: A review of current empirical research. Human Resource Management Review, 15, 69-95.

Hoch, J.E., \& Kozlowski, S.W.J. (2014). Leading virtual teams: Hierarchical leadership, structural supports, and shared team leadership. Journal of Applied Psychology, 99(3), 390-403.

Janssen, M., \& Joha, A. (2008). Emerging shared service organizations and the service-oriented enterprise: Critical management issues. Strategic Outsourcing: An International Journal, 1(1), 35-49.

Jarvenpaa, S.L., \& Leidner, D.E. (1998). Communication and trust in global virtual teams. Journal of Computer-Mediated Communication, 3(4), doi: 10.1111/j.1083-6101.1998.tb00080.x

Jarvenpaa, S.L., \& Leidner, D. (1999). Communication and trust in global virtual teams. Organization Science, 10(6), 791-815.

Johnson, S.K., Bettenhausen, K., \& Gibbons, E. (2009). Realities of working in virtual teams: Affective and attitudinal outcomes of using computer-mediated communication. Small Group Research, 40(6), 623-649.

Kanawattanachai, P., \& Yoo, Y. (2002). Dynamic nature of trust in virtual teams. The Journal of Strategic Information Systems, 11(3), 187-213.

Kirkman, B.L., Gibson, C.B., \& Kim, K. (2012). Across borders and technologies: Advancements in virtual teams research. In S.W. Kozlowski (Ed.), Oxford Handbook of Industrial and Organizational Psychology (vol. 1, pp. 789-858). New York: Oxford University Press.

Kirkman, B.L., \& Mathieu, J.E. (2005). The dimensions and antecedents of team virtuality. Journal of Management, 31(5), 700-718.

Kirkman, B.L., Rosen, B., Tesluk, P.E., \& Gibson, C.B. (2004). The impact of team empowerment on virtual team performance: The moderating role of face-to-face interaction. Academy of Management Journal, 47, 175-192.

Lipnack, J., \& Stamps, J. (1997). Virtual teams: Reaching across space, time and organizations with technology. New York, NY: Wiley.

Lipnack, J., \& Stamps, J. (1999). Virtual teams: The new way to work. Strategy \& Leadership, 27(1), 14-19.

Lipnack, J., \& Stamps, J. (2000). Virtual teams: People working across boundaries with technology, (2nd ed.). New York, NY: John Wiley \& Sons. 
Mackenzie, A. (2006). Java ${ }^{\mathrm{TM}}$ : the practical virtuality of internet programming. New Media \& Society, 8(3), 441-465.

Malhotra, A., Majchrzak, A., \& Rosen, B. (2007). Leading virtual teams. Academy of Management Perspectives, 21(1), 60-70.

Martins, L.L., Gilson, L.L., \& Maynard, M.T. (2004). Virtual teams: What do we know and where do we go from here?. Journal of Management, 30(6), 805-835.

Massumi, B. (2002). Parables for the virtual: Movement, affect, sensation. Durham, NC: Duke University Press.

Maynard, M.T., \& Gilson, L.L. (2013). The role of shared mental model development in understanding virtual team effectiveness. Group \& Organization Management, 39(1), 3-32.

Maynard, M.T., Mathieu, J.E., Rapp, T.L., \& Gilson, L.L. (2012). Something(s) old and something(s) new: Modeling drivers of global virtual team effectiveness. Journal of Organizational Behavior, 33(3), 342-365.

Maznevski, M.L., \& Chudoba, K. (2000). Building space over time: Global virtual team dynamics and effectiveness. Organizational Science, 11(5), 473-492.

Montoya-Weiss, M., Massey, A., \& Song, M. (2001). Getting it together: Temporal coordination and conflict management in global virtual teams. Academy of Management Journal, 44, 1251-62.

Mowshowitz, A. (1997). On the theory of virtual organization. Systems Research and Behavioral Science, 14(6), 373-384.

Nyström, C.A., \& Asproth, V. (2013). Virtual teams - Support for technical communication?. Journal of Organisational Transformation \& Social Change, 10(1), 64-80.

O'Keefe, M., \& Chen, E.T. (2011). The impact of emergent Web 2.0 on virtual teams. Communications of the IIMA, 11(2), 91-106.

Orhan, M.A. (2014). Extending the individual level of virtuality: Implications of task virtuality in virtual and traditional settings. Administrative Sciences, 4(4), 400-412.

Orhan, M.A., Rijsman, J.B., \& Van Dijk, G.M. (2016). Invisible, therefore isolated: comparative effects of team virtuality with task virtuality on workplace isolation and work outcomes. Revista de Psicología del Trabajo y de las Organizaciones, 32(2), 109-122.

Powell, A., Piccoli, G., \& Ives, B. (2004). Virtual teams: a review of current literature and directions for future research. ACM Sigmis Database, 35(1), 6-36.

Schiller, S.Z., \& Mandviwalla, M. (2007). Virtual team research - An analysis of theory use and a framework for theory appropriation. Small Group Research, 38(1), 12-59.

Schweizer, L., \& Duxbury, L. (2010). Conceptualizing and measuring the virtuality of teams. Information Systems Journal, 20(3), 267-295.

Shields, R. (2006). Virtualities. Theory Culture \& Society, 23(2-3), 284-286.

Serenko, A., \& Dumay, J. (2015). Citation classics published in knowledge management journals. Part I: articles and their characteristics. Journal of Knowledge Management, 19(2), 401-431.

Stanko, T.L., \& Gibson, C.B. (2009). Virtuality here and now: The role of cultural elements in virtual teams. In R.S. Bhagat \& R.M. Steers (Eds.), Cambridge Handbook of Culture, Organization, and Work (pp. 272-304). Cambridge, UK: Cambridge University Press.

Stemler, S. (2001). An overview of content analysis. Practical Assessment, Research \& Evaluation, 7(17), 137-146.

Styhre, A. (2006). Peer learning in construction work: Virtuality and time in workplace learning. Journal of Workplace Learning, 18(2), 93-105.

Townsend, A.M., DeMarie, S.M., \& Hendrickson, A.R. (1998). Virtual teams: Technology and the workplace of the future. Academy of Management Executive, 12, 17-29. 
Vartiainen, M. (2006). Mobile virtual work - concepts, outcomes and challenges. In E. Andriessen \& M. Vartiainen (Eds.), Mobile Virtual Work: A New Paradigm? (pp. 13-44). Heidelberg, Germany: Springer.

\section{Author}

\section{Mehmet A. Orhan}

Assistant Professor at the Faculty of Social Sciences of Charles University in Prague, Lecturer of Organizational Psychology at the Faculty of Arts of the same university and Faculty Member at the University of Liverpool Online Programmes. His research focuses on human-computer interaction in various domains, including organisational, educational and social settings. He obtained his PhD in Organizational Psychology from Tilburg University in the Netherlands.

Correspondence to: Mehmet A. Orhan, PhD, Charles University in Prague, Faculty of Social Sciences, Smetanovo Nabrezi 6, Prague, Czech Republic, e-mail: mehmet.orhan@fsv.cuni.cz

\section{Acknowledgements and Financial Disclosure}

The author would like to thank Prof. John Rijsman and Prof. Gerda van Dijk for their useful comments and support.

\section{Copyright and License}

This article is published under the terms of the Creative Commons

Attribution - NoDerivs (CC BY-ND 4.0) License

http://creativecommons.org/licenses/by-nd/4.0/

Published by the Centre for Strategic and International Entrepreneurship - Krakow, Poland 